\title{
ABSTRAK
}

\section{PENDIDIKAN KESEHATAN TERHADAP KETERAMPILAN REMAJA DALAM MEMBERI PERTOLONGAN PERTAMA PADA KASUS SYNCOPE}

\author{
Rusdi ${ }^{1}{ }^{*}$ \\ Program Studi Ilmu Keperawatan, Institut Teknologi Kesehatan dan Sains Wiyata Husada Samarinda ${ }^{1,2,3}$ \\ *Korespondensi: rusdi@itkeswhs.ac.id
}

Syncope dapat terjadi karena kurang aliran darah ke otak, karena terjadinya penurunan perfusi serebral, sebelum terjadinya pingsan akan ada episode presyncope. Tanda-tanda pingsan dilaporkan pasien seperti kram, mata berkunang-kunang. kondisi syncope apabila tidak ditangani akan berefek serius. Anak yang mudah syncope dapat beresiko kem atian sekalipun pada orang yang sehat bisa juga menyebabkan kematian tiba-tiba setelah episode syncope, selain menyebabkan kematian s yncope dapat menyebabkan cedera. Kejadian syncope biasanya sering dialami oleh siswa SD, SMP, dan SMA yang sedang menjalankan upacara bendera setiap hari Senin ataupun saat sedang berolah raga. Pelayanan siswa yang syncope di SMPN 7 Samarinda akan ditangani oleh anggota UKS dan pembina UKS. Biasanya siswa yang syncope akan dibawa keruangan UKS atau guru dan diberi teh hangat, minyak angin dan pakaian siswa dilonggarkan, jika siswa yang belum sadar langsung dibawah ke Puskesmas Bengkuring untuk mendapatkan perawatan medis. Anggota UKS menyatakan bahwa mereka masih kurang memahami penanganan saat terjadi kejadian kegawatdaruratan di sekolah terutama penanganan pada siswa syncope. Tujuan dari kegiatan ini untuk mengetahui pendidikan kesehatan terhadap keterampilan remaja dalam pemberian pertolongan pertama pada kasus syncope di SMPN7 Samarinda. Kegiatan ini dilaksanakan di SMPN 7 Samarinda pada tanggal 04 Maret 2018. Sasaran dari kegiatan ini adalah anggota UKS SMPN 7 Samarinda yang berjumlah 25 orang. Peningkatan jumlah siswa yang memiliki peningkatan keterampilan memberi pertolongan pertama pada kasus syncope Meningkatnya perilaku SMPN 7 Samarinda dipengaruhi oleh pemberian informasi yang mereka terima yang memberinya pendidikan Kesehatan dengan member simulasi pertolongan pertama pada kasus syncope.

Kata Kunci: Pendidikan Kesehatan, Syncope, dan Unit Kesehatan Sekolah

\section{PENDAHULUAN}

Kondisi kegawatdaruratan dapat menimpa siapa saja, tidak terduga, dapat terjadi dimana saja, dan terjadi kapanpun tanpa peringatan terlebih dahulu. Walaupun begitu tidak menutup kemungkinan kondisi kegawatdaruratan dapat terjadi pada daerah yang sulit dijangkau petugas kesehatan, maka dengan kondisi tersebut, peran serta masyarakat awam untuk membantu korban sebelum ditemukan oleh petugas kesehatan menjadi sangat penting (Sudiarto, 2011). Tiga persen sampai lima persen kasus yang masuk ke instalasi gawatdarurat adalah karena syncope dan menempati jumlah 1-3\% dari total pasien yang masuk rumah sakit. Dua puluh lima persen pasien syncope dapat ditegakkan diagnosanya setelah pemeriksaan fisik sedangkan pada $40 \%$ pasien syncope belum diketahui penyebabnya ( $\operatorname{Rad}$ et al, 2014).
Kejadian syncope biasanya sering dialami oleh siswa SD, SMP, dan SMA yang sedang menjalankan upacara bendera setiap hari senin ataupun saat sedang berolah raga. Sesuai dengan pendapat Shim et al (2014), bahwa seseorang dapat mengalami syncope karena lingkungan yang panas atau terpapar sinar matahari langsung, perlu pengetahuan yang baik untuk menangani siswa yang mengalami syncope saat di sekolah. Siswa yang syncope harus diposisikan supinasi dan dibawah ketempat yang teduh terl ebih dahulu. Setelah itu tinggikan posisi kaki 15 samapi $25 \mathrm{~cm}$ dari letak jantung agar darah mengalir ke otak, longgarkan pakaian bagian atas, usapkan kain basah atau dingin ke muka, periksa tanda-tanda vital dan ada cedera.

Pendidikan kesehatan adalah proses perubahan prilaku dimana perubahan tersebut 
terjadi karena adanya kesadaran dalam diri individu, masyarakat atau kelompok. Pendidikan kesehatan merupakan kegiatan yang membantu individu dalam bertindak secara mandiri dan membuat keputusan berdasarkan pengetahuan (Mukti, 2009). Penelitian Zuhri (2009) menjelaskan tentang pengaruh pendidikan kesehatan reproduksi terhadap tingkat pengetahuan remaja SMA Muhammadiyah Gabug, terdapat pengaruh yang signifikan pada tingkat pengetahuan setelah diberikan pendidikan kesehatan. Tingkat pengetahuan siswa saat pretest dalam kategori cukup $(82,4 \%)$ dan meningkat saat posttest menjadi baik $(96,9 \%)$ setelah diberikan Pendidikan Kesehatan.

Studi pendahuluan yang dilakukan di Sekolah Menengah Pertama Negeri 7 Samarinda (SMPN 7 Samarinda) didapat informasi dari guru bahwa anggota UKS di SMPN 7 Samarinda berjumlah 25 siswa Saat di lakukan wawancara pada anggota UKS, siswa pemah mengalami syncope saat upacara dihari senin dan dihari jumat saat berolahraga selalu ada siswa yang yang mengalami episode presinkop seperti mual, muntah, pusing dan pucat. Kejadian syncope pada siswa disebabkan karena lokasi upacara dihalaman sekolah yang terbuka dan terpapar smar matahari langsung, selain itu upacara juga mengharuskan siswa berdiri cukup lama. Pelayanan siswa yang syncope di SMP Negeri 7 Samarinda akan ditangani oleh anggota UKS dan pembina UKS. Biasanya siswa yang syncope akan dibawa keruangan UKS atau guru dan diberi teh hangat, minyak angin dan pakaian siswa dilonggarkan, jika siswa yang belum sadar langsung dibawah ke Puskesmas Bengkuring untuk mendapatkan perawatan medis. Anggota UKS menyatakan bahwa mereka masih kurang memahami penanganan saat terjadi kejadian kegawatdaruratan di sekolah terutama penanganan pada siswa syncope. Anggota UKS SMP Negeri 7 Samarinda belum pemah mendapat pendidikan kesehatan mengenai pertolongan pertama pada syncope maupun pendidikan kesehatan mengenai kegawatdaruratan sebelumnya.

Berdasarkan latar belakang diatas memotivasi penulis untuk meneliti apakah ada pengaruh pendidikan kesehatan terhadap keterampilan remaja dalam pemberian pertolongan pertama pada kasus syncope di wilayah kerja Puskesmas Bengkuring

\section{METODE}

Kegiatan ini dilaksanakan di Sekolah Menengah Pertama Negeri 7 Samarinda (SMPN 7 Samarinda) pada tanggal 04 Maret 2018. Sasaran dari kegiatan ini adalah anggota UKS SMPN 7 Samarinda yang berjumlah 25 orang. Kegiatan ini diawali dengan pengajuan proposal PKM pada bulan Februari, kemudian Pelaksanaan Kegiatan dimulai pada bulan Maret dan Pelaporan kegiatan dilakukan pada bulan April

\section{HASIL}

Responden yang terlibat dalam penelitian ini adalah responden yang sesuai dengan jumlah sampel yang ditentukan oleh peneliti yaitu 25 kelompok kontrol dan 25 Intervensi..

a. Perilaku sebelum pemberian pendidikan kesehatan terhadap keterampilan remaja dalam memberi pertolongan pertama pada kasus syncope.

Tabel 1. Distribusi Perilaku Sebelum Pemberian Pendidikan Kesehatan terhadap keterampilan remaja dalam memberi pertolongan pertama pada kasus syncope.

\begin{tabular}{|c|c|c|}
\hline $\begin{array}{c}\text { Sebelum pemberian } \\
\text { Pendidikan } \\
\text { Kesehatan }\end{array}$ & $\begin{array}{c}\text { Jumlah } \\
\text { (Orang) }\end{array}$ & $\begin{array}{c}\text { Persentase } \\
(\%)\end{array}$ \\
\hline Baik & 0 & 0 \\
\hline Cukup & 2 & 8 \\
\hline Kurang & 23 & 92 \\
\hline Total & $\mathbf{2 5}$ & $\mathbf{1 0 0}$ \\
\hline
\end{tabular}

Sebagaimana terlihat pada Tabel 1 ini kita melihat bahwa sebelum pemberian Pemberian Pendidikan Kesehatan terhadap keterampilan remaja 
dalam memberi pertolongan pertama pada kasus syncope sebagian besar responden sebanyak 23 orang $(92 \%)$. Hal ini dikarenakan kurangnya mendapatkan pelatihan dari pihak sekolah dan puskesmas sekitar tentang memberi pertolongan pertama pada kasus syncope dengan baik dan benar.

b. Perilaku sesudah pemberian pendidikan kesehatan terhadap keterampilan remaja dalam memberi pertolongan pertama pada kasus syncope.

Tabel 2. Distribusi Perilaku Sesudah Pemberian Pendidikan Kesehatan terhadap keterampilan remaja dalam memberi pertolongan pertama pada kasus syncope.

\begin{tabular}{|c|c|c|}
\hline $\begin{array}{c}\text { Sesudah pemberian } \\
\text { Pendidikan } \\
\text { Kesehatan }\end{array}$ & $\begin{array}{c}\text { Jumlah } \\
\text { (Orang) }\end{array}$ & $\begin{array}{c}\text { Persentase } \\
(\mathbf{\%})\end{array}$ \\
\hline Baik & 9 & 40 \\
\hline Cukup & 16 & 10 \\
\hline Kurang & 0 & 0 \\
\hline Total & $\mathbf{2 5}$ & $\mathbf{1 0 0}$ \\
\hline
\end{tabular}

Tabel 2. di atas, menjelaskan bahwa 25 responden terkait dengan sesudah pemberian pendidikan kesehatan Pemberian Pendidikan Kesehatan terhadap keterampilan remaja dalam memberi pertolongan pertama pada kasus syncope yaitu yang perilaku baik sebanyak 9 orang (40\%) sedangkan berprilaku cukup 16 orang (60). Hal ini dikarenakan mendapatkan pelatihan pertolongan pertama pada kasus syncope dengan benar yang mereka terima.

Hasil kegiatan ini menjelaskan tentang tujuan penelitian. Ada beberapa data yang perlu dipaparkan sebelum mengarahkan analisis yang akan menjawab tujuan penelitian. Data tersebut meliputi karakteristik responden.Responden dalam penelitian ini berjumlah 25 responden. a. Perilaku siswa SMP sebelum diberikan pendidikan kesehatan.

Rendahnya pengetahuan pertolongan pertama pada kasus syncope pada siswa SMP 7 Samarinda dipengaruhi oleh kurangnya informasi yang mereka terima dari sekolah maupun Puskesmas sekitar dan Pembina UKS. Hal serupa dikemukakan oleh Ningsih (2014), mengatakan bahwa rendahnya pengetahuan siswa tentang pendidikan keterampilan di pengaruhi oleh dua faktor yaitu keluarga dan faktor lingkungan sosial. Menurut Wong (2009), usia sekolah adalah anak pada usia 6-12 tahun, yang artinya sekolah menjadi pengalaman inti anak. Periode ketika anak-anak dianggap mulai bertanggung jawab atas perilakunya sendiri dalam hubungan dengan orang tua mereka, teman sebaya, dan orang lainnya.

Usia sekolah merupakan masa anak memperoleh dasar-dasar pengetahuan untuk keberhasilan penyesuaian diri pada kehidupan dewasa dan memperoleh keterampilan tertentu. Pengetahuan siswa SMP tentang cuci pertolongan pertama menurut Rahmawati (2014), menyatakan bahwa pengetahuan siswa perlu ditingkatkan melalui upaya-upaya konkrit yang dilakukan oleh masyarakat maupun lembaga pendidikan.Hal ini mengingat bahwa pengetahuan sangat diperlukan untuk menghindari adanya bahaya yang diakibatkan oleh pengetahuan yang rendah. Hasil observasi yang dilakukan oleh peneliti tekait metode ceramah. Metode ceramah yang terus yang terus menerus akan membuat siswa menjadi bosan. Pentingnya media yang menarik agar minat siswa tetap mengikuti pembelajaran dan mampu melatih kemampuan motorik halus siswa (Rahmawati, 2014). 
b. Perilaku siswa SMP sesudah diberikan pendidikan kesehatan.

Terjadi peningkatan keterampilan memberi pertolongan pertama pada kasus syncope kategori baik dari 0 menjadi 9 siswa (36\%). Peningkatan jumlah siswa yang memiliki peningkatan keterampilan memberi pertolongan pertama pada kasus syncope kategori baik disebabkan oleh meningkatnya perilaku praktik pertolongan pertama pada kasus syncope, yang bisa dilakukan oleh siswa sesuai dengan SOP.

Terdapat 9 siswa $(36 \%)$ yang memiliki keterampilan pertolongan pertama pada kasus syncope dengan kategori baik yang sebelumnya tidak ada yang berprilaku baik. Perilaku siswa dikatakan baik apabila pada hasil observasi check list pertolongan pertama pada kasus syncope yang dilakukan oleh peneliti, responden memiliki nilai berkisar 14 sampai 20. Sebanyak 9 (36\%) siswa kategori baik didistribusikan dari menurunnya jumlah keterampilan remaja member pertolongan pertama kategori cukup 16 ( siswa Peningkatan perilaku pertolongan pertama pada kasus syncope kategori cukup pada siswa didukung oleh metode simulasi yang dapat menarik perhatian siswa untuk mengikuti pembelajaran.

Perilaku siswa tentang pertolongan pertama pada kasus syncope ini lebih beragam (Heterogen) yang merupakan pengaruh dari pemberian pendidikan dengan kemampuan setiap responden dalam menerima dan memahami materi tentang pertolongan pertama pada kasus syncope yang diberikan berbeda-beda antara satu siswa dengan siswa yang lain. Pertolongan pertama pada kasus syncope yang dipraktikan secara tepat dan benar dapat mencegah terjadinya resiko cidera. pertolongan pertama (Notoadmojo, 2011 Syncope dapat mengurangi resiko terjadi cidera berbagai cidera termasuk Luka, Memar, Patah tulang. Meningkatnya perilaku siswa pertolongan pertama pada kasus syncope disebabkan pendidikan yang telah diberikan.

Pendidikan tersebut telah memberikan informasi kepada siswa tentang pertolongan pertama pada kasus syncope yang baik berupa pentingnya pengetahuan tersebut maupun bahaya yang ditimbulkan karena tidak tepat dalam memberi $\mathrm{p}$ ertolongan pertama. Berdasarkan teori, pengetahuan adalah hasil dari tahu, setelah orang melakukan pengindraan terhadap objek tertentu melalui indra penglihatan, pendengaran, rasa dan raga. Pengetahuan merupakan faktor yang sangat penting untuk terbentuknya perilaku dan informasi yang di dapat seseorang, karena perilaku yang didasari oleh pengetahuan akan langgeng dari pada perilaku yang tidak didasari pengetahuan (Notoatmojo, 2011).

\section{REFERENSI}

Ningsih R (2014). Penyuluhan hygiene sanitasi makanan dan minuman, serta kualitas makanan yang dijajakan pedagang di lingkungan SDN kota Samarinda. Jurnal Kesehatan Masyarakat, 10(1): 65.

Notoatmojo, S. (2011). Promosi kesehatan, teori dan aplikasi. Jakarta: Rineka Cipta.

Rad Assadian, M., Farahani, M., Emkanjoo, Z., Moladoust, H., \& Alizadeh, A. (2014). Predicting the outcome in patients with unexplained syncope and suspected cardiac cause: role of electrophysiologic studies. Anatolian journal of cardiology, 15(3), 213-217.

Rahmwati, D., Nugroho, S.E., dan Putra., N.M.D. (2014) Penerapan Model Pembelajaran Kooperatif Tipe Numberd Head Together Berbasis Eksperimen 
Jurnal Pengabdian Masyarakat Ners Wiyata

Volume 1 Nomor 1

Untuk Meningkatkan Keterampilan

Proses Sains Siswa SMP. Unnes Physics

Education Journal. 3 (1).

Shim, S. H., Park, S. Y., Moon, S. N., Oh, J. H., Lee, J. Y., Kim, H. H., Han, J. W., \& Lee, S. J. (2014). Baseline heart rate variability in children and adolescents with vasovagal syncope. Korean journal of pediatrics, 57(4), 193-198.

Wong, D.L. (2009). Buku ajar keperawatan pediatric. Jakarta: EGC 